In memoriam 



\section{Hanka Grupińska}

\section{Kazik, Simcha Ratajzer, a później Simcha Rotem}

\section{(10 lutego 1924, Warszawa - 22 grudnia 2018, Jerozolima)}

Rozumiem sens pisania o kimś, kto odszedł, a kto był ważny dla innych. Rozumiem, że chcemy o nim wiedzieć jeszcze coś, przypomnieć, zapamiętać... Ale też wiem, że to, co zapiszę poniżej, nie będzie o Kaziku - będzie o tym, jak go rozumiem, pamiętam, jak potrafię kilka zdań o nim napisać.

Stary kamienny dom w Jerozolimie. Posadzki z płytek ręcznie malowanych, barwne zdobienia. To była arabska dzielnica, Abu Tor. Do 1967 (od 1948) biegła tamtędy granica między nowym państwem Izrael a Jordanią. Kazik i Gina mieszkali tu od dawna. Może to tylko moja skrzywiona myśl, ale wydawało mi się, że nie byli tam do końca u siebie.

Niezwykły dom - z zewnątrz obleczony swoją arabską historią, dramatem uciekinierów, w środku przepełniony pastelową estetyką Giny i skrytością schowaną za ironią Kazika. Przyjechałam tam, bo Marek uważał, że trzeba rozmawiać z Kazikiem. 0 getcie, o powstaniu. W roku 1988 Kazik był jeszcze młody, Gina była ciągle piękna. Oboje poranieni przeszłością, oboje obrażeni na Polskę, na ludzi stamtąd. Gina uprzejmie powiedziała kilka zdań po angielsku. Kazik nie zgodził się na rozmowę o getcie. Wyszłam z poczuciem ulgi - mogłam dźwigać tamte opowieści, jeśli ktoś chciał się nimi dzielić, nie śmiałabym zadać jednego niechcianego pytania.

Wróciłam po dwóch, może trzech latach. Wiele się zmieniło. Stał się rok 1989. Kazik zaczął jeździć do Warszawy w interesach. Gina rozmawiała ze mną po polsku. Teraz mogłam już zadać wiele pytań. Rozmawialiśmy w ogrodzie, na basenie, na ulicach. Zawsze w Jerozolimie. Zapisałam tę skomponowaną sumę zdań w książce Ciągle po kole. Rozmowy z żydowskimi żołnierzami.

Kazik był uparty. - Wiem, co wiem, i pamiętam, co pamiętam - mówił. - Jakie bohaterstwo? - krzyczał - Czy myśmy zwyciężyli? Czy ja mogłem obronić swoich rodziców w getcie? Czy ja mogłem w ogóle kogoś obronić?! - Nie wpisywał się w żadne myślenie o Holokauście. Ani to izraelskie patriotyczno-propagandowe, ani to diasporowe, skupione na dramacie i zbiorowej traumie. Także dlatego 
był osobny. Bronił się ironią, czasem okrutnym cynizmem. Może i tego nauczył się od Marka Edelmana.

Przyjeżdżał do Polski coraz częściej. Wielu zaczęło przyjeżdżać. Kusiło ich to bycie tutaj, bo było bliskie. I odpychało, bo ciągle raniło: przeszłością, którą oni umieli czytać, i teraźniejszością, która potrafiła być podobnie nieczuła. Kazik Ratajzer/Simcha Rotem dostał w 2013 Krzyż Polonia Restituta. Był wtedy dumny. Słowami polskich polityków był oburzony - protestował kilkakrotnie. Przez kilka lat procesował się z dziennikarzem, który nazywając go „wielkim żydowskim bohaterem”, nie zawahał się wykorzystać jego prywatnych listów bez zapytania, bez zgody. Simcha Rotem wygrał upokarzający proces na chwilę przed odejściem. Był już bardzo chory, zmęczony czasem i doświadczaniem życia. Gina Rotem odeszła ze swojej twórczej samości kilka lat wcześniej, także po długim umęczeniu.

W mojej myśli mieszka Kazik niezależny, hardy, dumny, bezkompromisowy... Niechętny wszelkim „ustawkom” tego życia tu. Nie układał się z nikim, buntował się nawet przeciwko najbliższemu - Markowi Edelmanowi. Był sam w swoim świecie cierpienia. Pewnie bywał bardzo samotny. Z pewnością chciał być bardziej słyszany i lepiej rozumiany. 